\title{
Implementasi Nilai-Nilai Pendidikan Antikorupsi Pada Mata Kuliah Pancasila di Universitas Budi Darma Medan
}

\author{
Sumiaty Adelina Hutabarat ${ }^{1} *$ \\ ${ }^{1}$ Universitas Budi Darma Medan
}

\begin{abstract}
Abstrak-Korupsi penyakit menular yang sangat berbahaya merupakan masalah serius dalam setiap pemeintahan yang ada di dunia ini, dan bukan hanya masalah regional namun telah menjadi permasalahan internasional. Korupsi juga melanda lembaga dan profesi yang marak terjadi saat ini, termasuk lembaga pendidikan perguruan tinggi merupakan bagian dari korupsi itu sendiri. Komisi Pemberantasan Korupsi (KPK) telah memulai untuk memberantas korupsi melalui pendidikan anti korupsi yang ditanamkan secara terpadu termasuk perguruan tinggi. Hal ini disebabkan para koruptor adalah orang-orang pintar lulusan perguruan tinggi juga. Oleh sebab itu implementasi nilai-nilai pendidikan antikorupsi pada mata kuliah Pancasila di perguruan tinggi. Sehingga dapat menumbuhkan jiwa antikorupsi pada mahasiswa dan juga membangun mentalitas para generasi muda. Mengantikan para pejabat untuk bekerja secara jujur, tanggung, jawab dan adil. Tujuan penelitian ini mengetahui implementasi nilai-nilai pendidikan antikorupsi pada mata kuliah Pancasila, dan untuk mengetahui metode penanaman nilai-nilai pendidikan antikorupsi itu pada mata kulian Pancasila. Penelitian ini menggunakan metode kualitatif dengan teknik pengumpulan data dengan menggunakan teknik kuesioner pemahaman mahasiswa terhadap nilai-nilai pendidikan antikorupsi pada mata kuliah Pancasila menunjukan hasil yang baik artinya mahasiswa sudah mampu mengimplementasikannya namun belum menjadi karakter atau nilai pribadi pada mahasiswa Universitas Budi
\end{abstract} Darma Medan.

\author{
Kata kunci: \\ Pendidikan anti korupsi, \\ Matakuliah Pancasila
}

\section{Histori:}

Dikirim: 23 Agustus 2021

Direvisi: 24 Agustus 2021

Diterima: 30 September 2021

Online: 30 September 2021

(C)2021 JCC. All rights reserved

Author(s) agree that this article remains permanently open access under the terms of the Creative Commons Attribution-ShareAlike 4.0 International License

Identitas Artikel:

Hutabarat, S.A. (2021). Implementasi Nilai-Nilai Pendidikan Antikorupsi Pada Mata Kuliah Pancasila di Universitas Budi Darma Medan. Jurnal Citizenship Virtues, 1(2), 98-104.

\section{PENDAHULUAN}

Korupsi merupakan masalah serius dalam setiap pemeintahan yang ada di dunia ini, dan bukan hanya masalah regional namun telah menjadi permaslahan internasional yang melanda seluruh lapisan masyarakat dan merusak fondasi kehidupan. Korupsi bukan lagi milik politisi kalangan Dewan Perwakilan Rakyat (DPR), Dewan Perwakilan Rakyat Daerah (DPRD), termasuk juga kalangan birokrasi pemerintahan, pihak swasta, namun juga bersemai dan tumbuh di

\footnotetext{
${ }^{1}$ *Corresponding author.

E-mail: sumiatyadelina@gmail.com
} 
kalangan perguruan tinggi. Hal ini menunjukkan bahwa korupsi terjadi disemua lembaga dan profesi inilah yang sedang terjadi. Perguruan tinggi merupakan bagian dari korupsi itu sendiri. Modus korupsi di perguruan tinggi menurut Indriati (2014:29) a. Klickback dalam kontrak suplai konstruksi; b. Menahan atau memperlambat persetujuan dan tanda tangan yang diperlukan untuk memeras suap (hadiah, jasa, dan pembayaran segera); c. Mengarahkan agar pembengunan dan pengadaan barang dikerjakan oleh dirinya sendiri, keluarga, dan temannya; $d$. Mengurus pembayaran untuk pelayanan-pelayanan yang seharusnya diberikan gratis; e. Beban biaya yang ilegal; f. Pembelokan pemakaian uang sumbangan masyarakat. Sedangkan korupsi yang dilakukan di kalangan mahasiswa versi Komisi Pemberantasan Korupsi (KPK) yan diungkapkan wakil ketua KPK Saut Situmorang (beritajatim.com) a. Terlambat kuliah; b. Memberikan hadiah atau grafitasi kepada dosen; c. Mark up; d. Membuat proposal palsu; e. Penyalahgunaan dana beasiswa; f. Plagiasi; g. Mencontek; h. Titip absen. Penangkalan penceahan korupsi pemerintah Indonesia menerapkan suatu kebijakan yang kuat untuk memeranggi korupsi. Kebijakan yang berbeda tertuan dalam berbagai peraturan perundag-undangan, termasuk ketentuan Majelis Permusyawaratan Rakyat (MPR) tentang penyelenggaraan negara yang bersih dan bebas dari korupsi, kolusi, dan nepotisme. Undang-undang nomor 20 tahun 2001 yaitu Komisi Pemberantasan Korupsi (KPK) lembaga yang dibentuk dengan menelan biaya kurang lebih dari 6,4 miliar. Sejak berdirinya KPK banyak para koruptor yang tertangkap dan dipenjarakan, perhatian dan dukungan dari masyarakat dan lembaga anti korupsi kepada KPK, telah memperkuat tekad dan langkah dalam memberantas korupsi sampai ke akar-akarnya. Para koruptor justru semankin bertambah mencuri harta negara dan rakyat demi untuk kepentingan pribadi, kelompok dan keluarga. Hasil kuratif memberikan hasil seketika itu, tetapi karena luasnya spektrum perilaku korupsi, diperlukan upaya lain yang hasilnya tidak bisa dilihat sekarang, yaitu dengan diberikannya pendidikan antikorupsi pada mata kuliah Pancasila kepada mahasiswa khususnya Universitas Budi Darma Medan Mata kuliah Pancasila merupakan salah satu mata kuliah wajib umum diberikan kepada seluruh mahasiswa program studi calon sarjana danahli madya di Perguruan Tinggi seluruh Indonesia untuk mendampinging mata kuliah utama sesuai dengan jurusannya masing-masing. Berdasarkan Undangundang Nomor 12 tahun 2021 tentang Pendidikan tinggi dalam pasal 36 ayat (3) menegaskan kurikulum pendidikan tinggi sebagaimana dimaksud pada ayat 1 wajib memuat mata kuliah Pancasila. Oleh sebab itu mata kuliah Pancasila bertujuan untuk menanamkan nilai-nilai pendidikan antikorupsi untuk membentuk perilaku sikap antikorupsi, kolusi dan nepotisme. Nilai-nilai pendidikan antikorupsi sangat penting untuk ditanamkan kepada mahasiswa yang bukan hanya disiplin dalam mentaati peraturan saja namun harus dapat membangun sikap perilaku perseta didik untuk menjadi lebih baik lagi, apabila mahasiswa kelak sebagai generasi penerus bangsa sadar bahwa korupsi merupakan perbuatan melanggar hukum dan merugikan keuangan negara.

\section{METODE PENELITIAN}

Penelitian menggunakan metode kualitatif untuk menemukan esensi dari setiap fenomena. Strategi penelitian yang dikembangkan adalah studi kasus. 
Menurut Bogdan dan Taylor, dikutip oleh Moleong (2007:42) mendefinisikan metodologi kualitatif sebagai prosedur penelitian yang menghasilkan data deskripsi yang sumbernya berasal dari hasil wawancara dengan orang atau sikap yang diamati, serta berusaha mengambarkan suatu gejala peristiwa atau fenomena berdasarkan data empiris sebagai jawaban atas maslaha-masalah yang sedang diselidiki.

Hal ini disebabkan penelitian ini bertujuan untuk mendapatkan wawasan yang mendalam tentang implementasi dan metode penanaman nilai-nilai pendidikan antikorupsi pada mata kuliah Pancasila. Penelitian ini dilakukan di jalan Sisingamangaraja Nomor. 338 Kelurahan Siti Rejo I Medan, Kecamatan Medan Kota, Kotamadya Medan, Sumatera Utara 20219. Waktu penelitian dilaksanakan selama 3 (tiga) bulan terhitung sejak bulan Mei 2021 sampai dengan Agustus 2021. Sumber data primer dalam penelitian ini wawancara dengan informan yang sudah ditentukan dalam penelitian ini yaitu mahasiswa dari prodi Teknik Informatika angkatan 2018-2020 dengan dosen Universitas Budi Darma.

\section{HASIL DAN PEMBAHASAN}

Implementasi nilai-nilai pendidikan antikorupsi pada mata kuliah Pancasila pada Mahasiswa Universitas Budi Darma Medan mengambil sampel pada angkatan 2018-2020 dalam kaitannya dengan nilai-nilai pendidikan antikorupsi, dosen mata kuliah Pancasila telah memahami apa yang dimaksud dengan nilai- nilai pendidikan antikorupsi. Sebagaimana hasil wawancara dengan H.K Burian dosen Pancasila,"Pendidikan antikorupsi dapat dikatakan sama dengan pendidikan karakter, dimana mahasiswa diajarkan untuk memiliki sikap bertanggung jawab, kerja keras, percaya diri, tidak boros, hidup sederhana, dan jujur." Andayani dosen Pancasila,"Setuju dengan diberikannya pendidikan antikorupsi sebagai bekal bagi mahasiswa kedepannya mereka tidak akan berani lagi ataupun tidak akan ada niat setelah diuraikan bahwa apabila korupsi dilakukan hukum akan menjerat, dengan demikian tidak diperbolehkan menerima dalam bentuk apapun. Gaji yang telah diberikan dapat dimanfaatkan untuk kebutuhan hidup yang sederhana. Oleh sebab itu nilai-nilai pendidikan antikorupsi ada nilai tanggung jawab, keberanian mengatakan tidak kepada korupsi, kejujuran, disiplin, dengan demikian pelaksanaan nilai-nilai pendidikan antikorupsi bagi mahasiswa akan memiliki sikap yang lebih baik. Temuan dilapangan menunjukkan bahwa implementasi nilai-nilai pendidikan anti korupsi dilakukan dengan maksimal,karena mencakup pengembangan nilai-nilai pendidikan anti korupsi. Ketika proses pembelajaran dimasukkan nilai-nilai pendidikan antikorupsi kedalam materi yang diajarkan. Berdasarkan data yang diperoleh pada mata kuliah Pancasila, terlihat bahwa dosen menjelaskan meteri pembelajaran tentang makna kerjasama dalam kehidupan bermasyarakat yang didalamnya terdapat sub bab kerjasama dalam berbagai bidang kehidupan.dalam penjelasannya memiliki nilainilai anti korupsidalamproses belajar mangajar dosen mengintegritasikan nilainilai tersebut kedalam proses pembelajaran. Diharapkan mahasiswa mampu menghayati nilai-nilai pendidikan anti korupsi dengan menerapkannya dalam kehidupan sehari-hari, dengan mengembangkan sisiwa menjadi pribadi yang lebih baik dan pada akhirnya menjadi anti korupsi. Hal ini didukung oleh hasil wawancara dengan dosen agama Islam, Ustat Ilham yang menyatakan,"Ketika 
mempelajari topik yang ada hubungannya dengan pendidikan antikorupsi, saya biasanya mengkaitkannya dengan bentuk korupsi, dampak, jenis dan lain-lain saya biasanya menyisipkan pesan moral." Responden Aji mahasiswa Teknik Informatika menyebutkan pendidikan nilai-nilai antikorupsi pelajaran kejujuran yang harus ditanamkan sejak dini, sebagai acuan integrasi nilai-nilai korupsi,internalisasi, dan pendidikan agama sebagai landasannya agar pendidikan kedepan lebih baik dan bebas dari korupsi. Avie menyebutkan membangun nilainilai pendidikan antikorupsi dikalangan mahasiswa memberikan pengetahuan tentang korupsi dan pemberantasannya dan menanamkan nilai-nilai pendidikan anti korupsi. Berdasarkan hasil penelitian di Universitas Budi Darma Medan disimpulkan pertama Membangun budaya anti korupsi dikalangan mahasiswa dengan memberikan pengetahuan tentang korupsi dan pemberantasannya dengan menanamkan nilai - nilai anti korupsi serta mengetahui cara menghindari perbuatan korupsi dapat mengakibatkan hukuman bagi yang melakukan tindak pidana korupsi.

Metode dalam pendidikan salah satu aspekpenting yang diharapkan yang harus dimiliki dosen untuk menanamkan niali-nilai pendidikan anti korupsi di universitas Budi Darma Medan. Berdasarkan hasil wawancara dosen Pancasila HK. Burian mengungkapkan Metode keteladanan dilakukan dari rektor yang akan menegur dosen jika datang tidak tepat waktu, dilakukan dengan teguran tertulis yang artinya implementasi nilai disiplin tidak sebatas mahasiswa dimulai dari dosen yang menjadi sosok yang patut diteladanni. Siswa yang datang terlambat akan dikenakan sanksi skor pelanggaran, dosen juga harus menanamkan disiplin pada mahasiswa dengan memberikan tugas dan menyerahkannya tepat waktu. Jika seseorang tidak menyerahkan tugasnya tepat waktu, dosen akan menurunkan nilainya atau memberikan scor pelanggaran.lebih banyak dosen memberi contoh untuk bersikap baik, jujur ketika ada mahasiswa yang mengcopy paste tugasnya atau melakukan kesalahan dosen harus mengajarkan kepada mahasiswa bahwa membiasakan karakter yang baik itu penting, salah satu caranya adalah dengan melihat contoh yang diberikan dosen. Hal ini digunakan untuk proses pembelajaran agar dosen dan mahasiswa memiliki tanggung jawab dan disiplin yang sama sehingga mahasiswa dapat meniru sikap dosen. Adapun metode yang implementasikan dalam nilai-nilai pendidikan antikorupsi dalam mata kuliah Pancasilaadalah sebagai berikut:

Tabel 1.1 Nilai kedisiplinan

\section{No Penanaman Nilai disiplin}

1 Proses pembelajaran di daring tepat waktu dosen dan mahasiswa

2 Berpakaian rapi sesuai seragam yang telah ditentukan oleh akademik

3 Camera harus dinyalakan saat perkuliahan

Tabel 1.2 Nilai Kemandirian

\begin{tabular}{ll}
\hline No & Penanaman Kemandirian \\
\hline 1 & Tidak boleh bergantung kepada orang lain dalam membuat tugas \\
2 & Tugas rumah harus dikerjakan sendiri \\
3 & Dilarang copy paste milik orang lain \\
\hline
\end{tabular}


Tabel 1.3 Nilai Kepedulian

\begin{tabular}{ll}
\hline No & Penanaman Kepedulian \\
\hline 1 & Peduli terhadap sesama \\
2 & Memberi bantuan kepada orang yang membutuhkan \\
3 & Menjaga kebersihan lingkungan \\
\hline
\end{tabular}

Tabel 1.4 Nilai Tanggung Jawab

No Penanaman Tanggung jawab

1 Tanggung jawab terhadap tugas dan kewajiban

2 Tanggung jawab menjaga kebersihan dengan melarang buang sampah sembarangan

3 Tanggung jawab terhadap Tuhan menjalankan ibadah agama menurut agama dan kepercayaannya masing-masing

Tabel 1.5 Nilai Kejujuran

No Penanaman Kejujuran

1 Jujur dalam perkataan maupun perbuatan

2 Apabila meminjam barang kepada orang lain harus diberitahu

3 Jujur dalam kemampuan yang dimiliki

Tabel 1.6 Nilai Keadilan

\begin{tabular}{ll}
\hline No & Penanaman Keadilan \\
\hline 1 & Tidak boleh memilih-milih dalam berteman antara yang kaya dan miskin \\
2 & Tidak memihak dan pilih kasih \\
3 & Tidak berpihak kepada yang salah \\
\hline
\end{tabular}

Tabel 1.7 Nilai Kesederhanaan

\begin{tabular}{cl}
\hline No & Penanaman Kesederhanaan \\
\hline 1 & Bersahaja tidak banyak pernik \\
2 & Tidak berlebihan apa adanya \\
3 & Tidak banyak seluk-beluk rendah hati \\
\hline
\end{tabular}

Tabel 1.8 Nilai Kerja Keras

\begin{tabular}{cl}
\hline No & Penanaman Kerja Keras \\
\hline 1 & Mengerjakan tugas dengan baik \\
2 & Menolong orang tua dalam pekerjaan rumah \\
3 & Memiliki perilaku sungguh-sungguh dalam mengatasi hambatan dalam \\
& berlajar dan membuat tugas \\
\hline
\end{tabular}

Tabel 1.9 Nilai Keberanian

\begin{tabular}{cl}
\hline No & Penanaman Keberanian \\
\hline 1 & Mempunyai hati yang mantap dan percaya diri \\
2 & Tidak takut dan gentar
\end{tabular}


Kegiatan penelitan dengan menyebarkan kuesioner kepada mahasiswa di era pandemi melalui group WhatsApp mata kuliah Pancasila Prodi Teknik Informatika. Jumlah keseluruhan mahasiswa diberikan kuesioner 100 orang dengan jumalah mahasiswa laki-laki 57 orang dan mahasiswa perempuan 43 orang. Terdiri dari semester 8 kelas pagi, sore, mahasiswa aktif organisasi dan tidak ikut organisasi, yang telah mengikuti mata kuliah Pancasila, dengan data sebagai berikut: bahwa 100 orang responden yang telah dibagikan implementasi nilai-nilai pendidikan antikorupsi pada mata kuliah Pancasila berada dalam katagori kriteria cukup baik, baik, dan sangat baik. Cukup baik sebanyak 4\% dari responden, baik $15 \%$, sangat baik $81 \%$. Sehingga dari data tersebut $96 \%$ dikatorikan baik dan sangat baik. Sehingga ditarik kesimpulan bahwa mayoritas mahasiswa dalam mengimlementasikan nilai-nilai pendidikan antikorupsi dalam mata kuliah Pancasila sangat baik. Dapat digambarkandalam tabelperentasi berdasarkan masing-masing kriteria, sebagai berikut:

Tabel 2.1 Persentase Pemahaman Mahasiswa

\begin{tabular}{lclc}
\hline No & Angka & Predikat & Jumlah Respon \% \\
\hline 1 & $0 \%-20 \%$ & Sangat buruk & - \\
2 & $21 \%-40 \%$ & Buruk & - \\
3 & $41 \%-60 \%$ & Cukup baik & $4 \%$ \\
4 & $61 \%-79 \%$ & Baik & $15 \%$ \\
5 & $80 \%-100 \%$ & Sangat baik & $81 \%$
\end{tabular}

Sumber data: diolah dari hasil kuesioner

Tabel 2.2 Persentase berdasarkan hasil kuesioner

\begin{tabular}{cccc}
\hline No & Pilihan Jawaban & Jumlah Keseluruhan & Persentase \\
\hline 1 & Tidak pernah & 4 & $4 \%$ \\
2 & Kadang-kadang & 15 & $15 \%$ \\
3 & Sering & 29 & $29 \%$ \\
4 & Selalu & 52 & $52 \%$ \\
\hline
\end{tabular}

Sumber data: diolah dari hasil kuesioner

Berdasarkan data tersebut $81 \%$ responden menjawab sering dan selalu. Jadi kesimpulan mayoritas responden atau mahasiswa selalu mengimplementasikan nilai-nilai pendidikan antikorupsi dalam kehidupan seharihari di lingkungan masyarakat. Dari hasil analisa tersebut menunjukan bahwa sebanyak 96\% mahasiswa yang berada ditingkatan pemahaman baik dan sangat baik. Sedangkan pada tingkat pemahaman mahasiswa yang sering dan selalu sebanyak $81 \%$ menerapkan nilai-nilai pendidikan antikorupsi dalam kehidupan sehari-hari. Kadang-kadang 15\%, tidak pernah. 4\%. Melalui implementasi pendidikan nilai-nilai antikorupsi pada mata kuliah Pancasila di Universitas Budi Darma Medan diharapkan akan lahir generasi tanpa korupsi, sehingga dimasa yang akan datang negara Republik Indonesia bebas dari penyakit korupsi. 


\section{KESIMPULAN}

Berdasarkan hasil penelitian di Universitas Budi Darma Medan disimpulkan pertama Imple mentasi nilai-nilai pendidikan antikorupsi memberikan pengetahuan tentang korupsi dan pem berantasannya dengan menanamkan nilai nilai anti korupsi serta mengetahui cara menghin dari perbuatan korupsi sehingga dapat meminimalisir penyebab terjadinya korupsi baik di pemerintahan maupun di masyarakat; kedua metode ketelandan melalui implementasi nila-nilai pendidikan antikorupsi pada mata kuliah Pancasila di Universitas Budi Darma telah menunjukan implementasi dalam kehidup sehari-hari sangat baik. akan lahir generasi tanpa korupsi, sehingga dimasa yang akan datang negara Republik Indonesia bebas dari penyakit korupsi.

\section{REFERENSI}

Beritajaticom (2019) Inilah 8 Modus Korpsi di Kalangan Mahasiswa versi KPK [HTML file] Tersedia: https://beritajatim.com/hukum-kriminal/inilah-8modus-korupsi-di-kalangan-mahasiswa-versi-kpk/

Indriati, Etty. (2014). Pola dan Akar Korupsi. Gramedia.

Lexy J. Moleong. (2007). Metodologi Penelitian Kualitatif. Renaja.

Rosdakarya Raharjo. S. (2000). Ilmu Hukum. Citra Aditya Bakti.

Sumiaty Adelina Hutabarat (2020). Modul Pendidikan Pancasila di Perguruan Tinggi Civic Education. Jatim: Wais Inspirasi Indonesia.

Setiyawati. dkk (2017). Buku Seri Pendidikan Antikorupsi Dampak Korupsi. Tirta Asih Jaya.

Surachmin. Suhandi Cahaya. (2011). Strategi Dan Teknik Korupsi. Sinar Grafika. Susilo. Sutarjo. (2013). Pembelajaran Nilai-Nilai Karakter. Rajawali Pres.

Taniredja.Tukiran. (2013). Konsep Dasar Pendidikan Kewarganegaraan. Ombak Dua.

Wijaya David. (2014). Pendidikan Antikorupsi Untuk Sekolah Dan Perguruan Tinggi. Indeks Permata Puri Media. 